\title{
Calendar \\ Lumbar Spinal Stenosis \\ Controversies in Etiopathogenesis, Management and Costs
}

Brussels, Belgium, November 20-21, 1998

Contact: R. Gunzburg, M.D., Ph.D., Brugmann University Hospital, Department of Orthopaedics, 4, Place van Gehuchten, 1020 Brussels, Belgium; Fax: 32/2/478 00 91, 32/3/240 2040. 